\title{
The Impact of Perceived Social Media Marketing Activities: An Empirical Study in Saudi Context
}

\author{
Maha M. Khan ${ }^{1}$ \\ ${ }^{1}$ King Saud University, Riyadh, Saudi Arabia \\ Correspondence: Maha M. Khan, MBA student at King Saud University, Riyadh, Saudi Arabia. E-mail: \\ maha.mk11112@gmail.com
}

Received: January 13, 2019 Accepted: February 6, $2019 \quad$ Online Published: February 27, 2019

doi:10.5539/ijms.v11n1p134 URL: https://doi.org/10.5539/ijms.v11n1p134

\begin{abstract}
Purpose - The purpose is to investigate the impact of social media marketing activities in the context of Saudi consumers of social media. A research model is developed in this study to examine the relationships.
\end{abstract}

Design/methodology/approach - This research is quantitative and uses the probability sampling technique, simple random sampling. Data is collected through a questionnaire in a survey of 241 Saudi social media users. Structural equation modeling (SEM) with PLS 3 was used with SPSS 22.0 for statistical data analysis. Chi-square and overall model fit indices further confirm the structural model fit.

Findings - The results indicate that social media marketing activities significantly influence brand loyalty, purchase intentions, value consciousness and brand consciousness; brand loyalty has a significant statistical impact on eWOM; eWOM influences purchase intention significantly; brand consciousness does not mediate the relationship between perceived social media marketing and brand loyalty, while value consciousness mediates this relationship.

Research limitations/ future research - The research is limited to Saudi social media users and this limits the results from being generalized. Future research must be conducted in other countries. Moreover, limited research is conducted with these variables in previous studies.

Originality/value - This article is pioneering in that it investigates the effects of social media marketing in the context of Saudi consumers, a topic of relevance for both marketers and scholars in the era of social media. It provides empirical evidence and valuable insights through a proposed model.

Keywords: social media marketing, brand loyalty, value consciousness, brand consciousness, eWOM, purchase intention

\section{Introduction}

Social media marketing activities have been recognized as one of the most influential sources of marketing for reaching a greater audience and growing business. The emergence of social media sites has changed the way marketers interact with customers. This phenomenon impacts consumers as it affects their purchase intentions. Social media has become an important communication channel for marketers as it influences consumers when they are purchasing products and services. It has inevitably improved how consumers and marketers communicate (Hennig-Thurau et al., 2004). Consumers voice, network with and share their experiences with anyone in the world through social media (Kozinets et al., 2010). Usage of social media has increased and consumers rely on this medium of communication, affecting their purchase intentions and the decision making process. It increases the consumer confidence in the purchase and reduces their uncertainty in the purchase process. In this era, the integration of social media marketing in the marketing activities is necessary for business growth, reaching a greater audience, improving brand loyalty and brand awareness, engaging and interacting with customers, building brand reputation, and increasing sales and profits. Marketers and practitioners have new challenges and opportunities within the area of social media marketing. From 2008 to 2012, companies' consumption of social media rose from $42 \%$ to $88 \%$ whereby it was utilized for marketing, advertising, idea innovation, customer engagement and service (Smith, Fischer, \& Yongjian, 2012). Businesses had to review their strategies for customer collaboration (Kaplan \& Haenlein, 2010) as futurists had not predicted the speed with which social media invaded marketing and other business practices (Aburdene, 2005). The impact of social 
media on consumer behavior has made it essential for them to understand the social media and its application for businesses in order to achieve their goals.

Kaplan and Haenlein (2010, p. 61) define social media as "a group of Internet based applications that build on the ideological and technological foundations of Web 2.0, and allow the creation and exchange of user generated content." These internet based applications include weblogs, social blogs, microblogging, wikis, podcasts, pictures, video, rating and social bookmarking. Through all practices of social media such as networking sites, content communities, virtual worlds, blogs, microblogging sites, online gaming sites, social bookmarking, news sites, and forums, products and services can be promoted by businesses, instant support can be provided, and an online community of brand devotees can be created (Erdogmus \& Cicek, 2012; Zarella, 2010; Kaplan \& Haenlein, 2009; Weinberg, 2009). Moreover, through social media, information about product and service brands is shared by consumers with their peers (Stileman, 2009; Mangold \& Foulds, 2009). Growing platforms of social media marketing are Twitter, Instagram, Snapchat, Facebook, Blogs, Pinterest, LinkedIn, Google + and forums. These communication channels make the companies reachable to customers.

For organizations, social media is a competitive platform for marketing, in terms of building brand loyalty and positive e-Word of Mouth, targeting brand conscious and value conscious consumers, and influencing their purchase intentions. This paper discusses the impact of social media marketing on brand loyalty, given that the concept is receiving increasing attention from marketing academia and practitioners (Erdoğmuş \& Cicek, 2012; Zarella, 2010). Moreover, social media marketing affects the purchase orientation of value conscious and brand conscious consumers. Customers who seek better prices and the best value for money are value conscious consumers, and those who regard brands as a symbol of stature and buy well-known brands are brand conscious consumers. These customers have different associations with brand loyalty. This study investigates the effect of social media marketing on brand consciousness and value consciousness, and the effect of brand consciousness and value consciousness on brand loyalty. Additionally, brand loyalty leads to positive e-word of mouth. Those who are loyal to the brand share good experiences and give positive recommendations of the brand online, and brand loyalty has been assimilated with diffusing a positive eWOM (Tiago \& Veríssimo, 2014). Henceforth, this study examines the relationship of brand loyalty in influencing eWOM. Online product reviews are a common platform for customers where they can gather product information and form purchase intentions. Based on this, we understand that eWOM can affect purchase intentions.

The research is conducted in the context of Saudi Arabia, as the internet penetration rate in the country has reached $91 \%$ in 2018, with the number of internet users approximately at 30 million from a population of nearly 33 million people (Global Media Insight, 2018). From this population 25 million (75.19\%) are active social media users (Global Media Insight, 2018). As of 2017, the penetration rates of leading social media sites are $71 \%$ for Youtube, $66 \%$ for Facebook, 54\% for Instagram, 52\% for Twitter, 39\% for Snapchat, and 32\% for GooglePlus (Statista, 2017). Among the most popular social media platforms in KSA in 2018, Youtube boasts 23.62 million active users, while Facebook is second with 21.95 million users, Instagram is third with 17.96 million users, Twitter is fourth with 17.29 million users, and Google+ is fifth with 10.64 million users (Global Media Insight, 2019). In the light of these statistics, Saudi Arabia provides a valid platform to study social media.

\subsection{Research Questions}

To investigate the literature gaps addressed above, the following research questions arise for the purpose of this study:

- What is the impact of social media marketing activities on Saudi consumers?

- Do social media marketing activities influence brand loyalty, purchase intention, value conscious and brand conscious customers?

- Does brand loyalty relate to eWOM?

- Does eWOM influence consumers' purchase intention?

\subsection{Research Objectives}

For the guidance of answering the research questions, the following research objectives are formulated:

RO1: To address the impact of social media marketing activities in the context of Saudi consumers.

RO2: To explain the impact of social media marketing on brand loyalty, value consciousness, brand consciousness and purchase intention.

RO3: To investigate the impact of value consciousness and brand consciousness on brand loyalty, and the 
mediating effect of value consciousness and brand consciousness on the relationship between social media marketing and brand loyalty.

RO4: To determine the impact of brand loyalty on eWOM.

RO5: To determine the impact of eWOM on purchase intention.

\subsection{Problem Statement}

The main purpose of this paper is to understand and investigate the effects of social media marketing in the context of Saudi consumers of social media. It addresses the impact of social media marketing on brand loyalty, brand consciousness, value consciousness, and purchase intentions; the impact of brand loyalty on eWOM and of eWOM on purchase intentions.

\subsection{Importance of the Study}

Previous studies have discussed the effect of social media marketing on brand loyalty, and the mediating effect of value consciousness and brand consciousness on the relationship between social media marketing and brand loyalty. This study tests the model (Ismail, 2017) in the context of Saudi Arabia, and developed a conceptual model that relates further, the variables, brand loyalty to eWOM, eWOM to purchase intentions, and perceived social media marketing to purchase intentions. Although the topic is discussed in literature, there is lack of research among the variables discussed. To address the research void, a research model is developed to investigate the relationships among social media marketing, brand loyalty, brand consciousness, value consciousness, eWOM and purchase intentions. The second goal, as empirical studies discussing this literature in the Saudi context are limited, this article addresses this knowledge gap by investigating the framework of relationships among the study variables in the light of Saudi consumers of social media. Addressing the modern changes in marketing communication, this article provides a better understanding of the effects of social media marketing. It confirms the growing importance of social media marketing and indicates that practitioners should implement social media marketing strategies.

The study applies a quantitative analysis techniques that attempts to investigate (1) the impact of social media marketing on brand loyalty, brand consciousness, value consciousness, and purchase intention (2) the mediating effects of brand consciousness and value consciousness on the relationship between perceived social media marketing activities and brand loyalty (3) the impact of brand loyalty on eWOM (4) the impact of eWOM on purchase intention.

\section{Literature Review}

\subsection{Perceived Social Media Marketing}

Social media marketing is "a broad category of advertising spending, including advertising using social network, virtual worlds, user-generated product reviews, blogger endorsement, RSS feeds of content and social news sites, podcasts, games, and consumer generated advertising" (Tuten, 2008, p. 9). Social media marketing shall be defined as "a social and managerial process by which individuals and groups obtain what they need and want through" (Kotler, Bowen, \& Makens, 2006, p. 30) a set of Internet-based applications that enable interaction, communication, collaboration of user-generated content and hence, sharing of information such as ideas, thoughts, content, and relationships (Chan \& Gulliet, 2011). Social media activities of brands give an opportunity to reduce misunderstanding and bias toward brands, and to elevate brand value by creating a platform to exchange ideas and information among people online (Kim \& Ko, 2012). Firms adopt social media for various marketing activities such as branding, market research, customer relationship management, service provision, and sales promotion alongside various studies that are putting forward evidence of the positive implications of deploying social media in marketing strategies (Alves, Fernandes, \& Raposo, 2016). With the social media communication channel, businesses and organizations connect with peers, customers and prospective customers by sending commercial messages through the different forms of social media such as social blogs, weblogs, pictures, rating, wikis and podcasts for advertising and marketing at low costs and less work than before. Messages on social media contribute to improved attitudes towards the brand, increased word of mouth and equity (Cambria et al., 2012). The best means embraced by companies to improve attitude towards the brand are social networks and blogs such as Twitter and Facebook (Leung, Bai, \& Stahura, 2015). Moreover, social media can be used to generate increased sales, return on investment, word of mouth, and spread information about brands (Yu et al., 2013). As customers receive information and interact with the brand on social media, they form a relationship with the brand that would, with a strong favorable attitude towards advertising and promotions, lead to brand loyalty and influence their purchase intentions. 


\subsection{Brand Consciousness}

Brand consciousness refers to the mental orientation to select products that are well-known and highly advertised brand name (Sproles \& Kendall, 1986). Brand conscious consumers use brands to portray their fashion consciousness, express their personality, and reduce risk in purchase decisions (Liao \& Wang, 2009). In other words, strong brand consciousness in consumers refers to those who seek greatly promoted, well-known, and expensive brands. Brand consciousness is defined as a concept that brand names are important in the psychological prepurchase process, (Nelson \& McLeod, 2005; LaChance et al., 2003) the process that precedes the buying act. Despite its importance, the impact of perceived social media marketing activities on brand consciousness remains relatively unknown (Ismail, 2017). As brand information is shared at low costs among firms, consumers, and their peers, this increases brand awareness, brand loyalty and enhances brand recognition (Gunelius, 2011). Through social media, firms build brand loyalty through networking, conversation, and community building (McKee, 2010). Moreover, highly brand conscious consumers may buy expensive brands and remain loyal to the brand not because of quality perceptions per se, but because others may perceive them as socially positive due to the high price (Ismail, 2017; Bao \& Mandrik, 2004). This study assumes that social media marketing activities influence brand consciousness and brand consciousness has an impact on brand loyalty. It also assumes that brand consciousness mediates the relationship between social media marketing and brand loyalty.

\subsection{Value Consciousness}

Value consciousness has been conceptualized "as the concern for paying low prices, subject to some quality constraints" (Lichtenstein et al., 1990, p. 56). Consistent with this definition, Zeithaml (1988) suggested "value is the quality I get for the price I paid," interpreting the meaning of value used by many customers. Value-conscious individuals are more likely to consider "value in use" and thus are more likely to seek "value for money" information (Lichtenstein et al., 1990). They are also more likely to use social media platforms regularly to shop for the lowest prices with a number of major benefits, such as, saving money by enabling them to achieve lowest price, finding the right products to satisfy their needs and compare other prices from different brands. This study assumes that social media marketing affects value consciousness and value consciousness affects brand loyalty. It further assumes that value consciousness mediates the relationship between social media marketing and brand loyalty.

\subsection{Brand Loyalty}

Brand loyalty is an emotional or psychological attachment to a brand (Fournier, 1998). Aaker (1991) defines brand loyalty as the attachment that a customer has to a brand. Yoo and Donthu (2001) define brand loyalty on an attitudinal perspective as the tendency to be loyal to a focal brand, which is demonstrated by the intention to buy the brand as a primary choice. Customers are willing to be loyal to companies that will deliver added value in comparison to competitors' offering (Reichheld et al., 1996). When people are loyal to a brand, they show an intense positive attitude of commitment to the brand and this in effect causes them to support it (Choi et al., 2018; Lobschat et al., 2013). Erdoğmuş and Çiçek (2012) investigated the relationship between social media marketing and brand loyalty in Turkey on customers who followed at least one brand on the social media. It showed that customer's brand loyalty was affected by the social media marketing of the brand. This study assumes that brand loyalty will be significantly influenced by social media marketing.

As social media users become emotionally and psychologically attached to a brand, they are more likely to be engaged in delivering information about it to other users (Choi et al., 2018; Yeh \& Choi, 2011). This indicates that brand loyalty affects eWOM. According to the theory of reasoned action (TRA) (Fishbein \& Ajzen, 1975), it provides background information useful in understanding the relationship between brand loyalty and eWOM, and between eWOM and purchase intentions. TRA assumes human beings make reasonable decisions. People make reasonable decisions whereby the beliefs result in attitudes, which in turn lead to behavioral intentions, which ultimately lead to actual behaviors (McKnight et al., 2002). To share information with other customers and peers, and give recommendations online is a behavioral consequence of brand loyalty, the attitude that would lead to eWOM. Tiago and Verissimo (2014) suggest that brand loyalty is associated with diffusing positive E-WOM. This study assumes that brand loyalty affects eWOM.

\subsection{Electronic Word of Mouth (eWOM)}

eWOM is defined as any statements made by future, present or former customers about a product or enterprise, either positive or negative, and is accessible by anyone online (Henning Thurau et al., 2004). Electronic Word of mouth can be described as a communication way that provides information to consumers about sellers and usage of products and services through internet-based technologies (Torlak et al., 2014; Westbrook, 1987). When 
consumers gather information about products before they make the actual purchase and while forming purchase intentions, it is gradually more common for them to refer to online product reviews (Jalilvand \& Samiei, 2012). Electronic word of mouth critically affects consumers' product reviews and their purchase intention (Torlak et al., 2014; Zhu \& Zhang, 2010; BambuerSachse \& Mangold, 2011). Moreover, in the social media environment, loyal consumers usually tend to be brand ambassadors for other consumers (Rialti et al., 2017; Burmann, 2010). Eventually, members of a brand community tend to adopt this behavior, diffusing positive information concerning brands (Rialti et al., 2017; Zaglia, 2013). When customers review product information and recommend others, based on prior experience or knowledge about the product from social media marketing, this could boost purchase intentions and motivate them to buy. Therefore, this study assumes that eWOM is influenced by brand loyalty and eWOM affects purchase intentions.

\subsection{Purchase Intentions}

Intention is the behavior that motivates person sense to perform behavior (Rezvani et al., 2012). Purchase intention is a combination of consumers' interest in and possibility of buying a product (Kim \& Ko, 2012). As a result of many studies, it strongly relates to attitude and preference toward a brand or a product (Kim, Kim, \& Johnson, 2010; Kim \& Ko, 2010b; Kim \& Lee, 2009; Lloyd \& Luk, 2010) so that measuring purchase intention assumes consumers' future behavior based on their attitudes. The exchange of information, feedback, and ratings on social media platform overcome the barrier of insecurity and increase the trust of the consumers and consequently lead to the willingness to purchase the product or service (Bong, 2017; Hajli, 2014). This study assumes that social media marketing will influence purchase intentions significantly. With the advent of Web 2.0 technology, eWOM has a critical impact on consumers' purchase intentions, as consumers trust on eWOM before making any product purchase (Doh \& Hwang, 2009). We assume that purchase intention is likely influenced when users receive positive eWOM messages.

\section{Research Model}

With respect to what has been discussed so far, the proposed model of this research is shown in Figure 1. The main contribution of this research is examining the influence of social media marketing activities in the context of Saudi social media users.

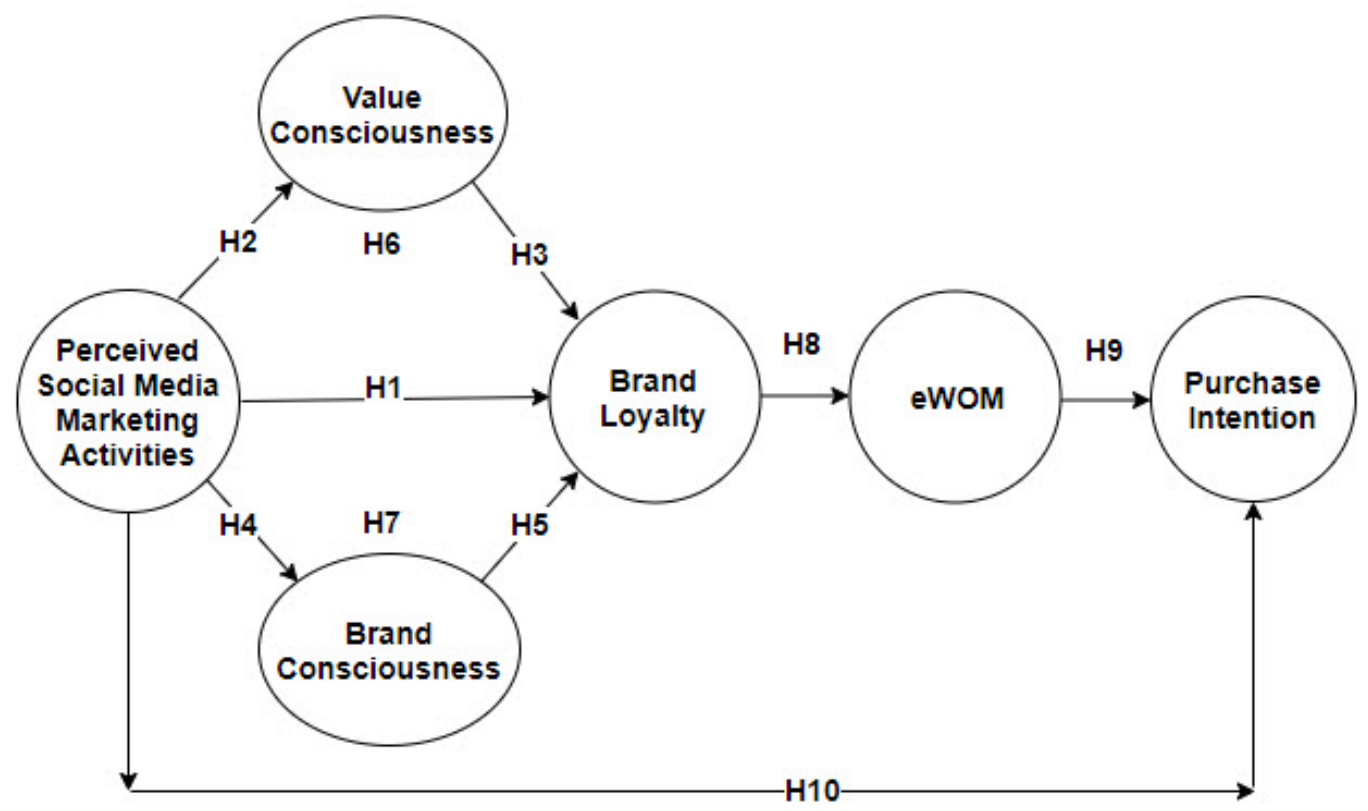

Figure 1. Research model

\subsection{Research Hypotheses}

The model of research forms the research hypotheses for this study. They are as follows:

H1: Perceived social media marketing activities has a direct significant statistical effect on brand loyalty.

$\mathrm{H} 2$ : Perceived social media marketing activities has a direct significant statistical effect on value consciousness. 
H3: Value consciousness has a direct significant statistical effect on brand loyalty.

H4: Perceived social media marketing activities has a direct significant statistical effect on brand consciousness.

H5: Brand consciousness has a direct significant statistical effect on brand loyalty.

H6: Perceived social media marketing activities has an indirect significant statistical impact on brand loyalty as mediated by value consciousness.

H7: Perceived social media marketing activities has an indirect significant statistical impact on brand loyalty as mediated by brand consciousness.

H8: Brand loyalty has a direct significant statistical effect on eWOM.

H9: eWOM has a direct significant statistical effect on the purchase intention.

H10: Perceived social media marketing activities has a direct significant statistical effect on purchase intention.

\section{Research Methodology}

\subsection{Sample and Data Collection}

The population in this study, considering the research variables, includes all the Saudi users of social media sites. In this study, the probability sampling technique is used to manage the users' survey. Data is collected by the simple random sampling method. Random samples were drawn from the Saudi population. Since the study focuses on analyzing the influence of social media marketing, the selected respondents were restricted to consumers who had accounts on Social media sites. To qualify for the study, the respondents needed to be social media users and Saudi citizens and residents. Participation in the survey was from both male and female genders in Saudi Arabia.

To collect the data, a questionnaire was used. Data was collected by survey questionnaires that were distributed as online survey and offline survey from October 28 to December 18, 2018. The link to the questionnaire was posted several times on Twitter and LinkedIn, and shared on social media sites including WhatsApp and Snapchat. The invitation to the survey informed about the topic of the study and asked the respondents to share the post with their friends on the sites they communicate with, including WhatsApp, Twitter, Snapchat, and LinkedIn. To ensure that the respondents qualify for the study, a screening question was inserted. The question asked the respondents if they have accounts on social media. Saudi members of a social media site were the target sample in this study. Those respondents were not included into the data set who fail to pass the screening question. Participants were asked to list the social media sites they use (Twitter, Snapchat, Instagram, Google +, Facebook, etc.), the time they spend on online social media activities (everyday, 4-5 days a week, once or twice a week, very rare), and the products they purchase through online social media (books/magazines/newspapers, computers \& electronics, hair \& skin products, event tickets, clothing \& accessories, travel/hotel arrangement, etc.). Then, keeping in mind a brand on social media sites, they answered questions related to the constructs of interest, the items related to each variable under study, followed by demographic questions (sex, age, education, nationality). We considered only fully completed surveys. Incomplete questionnaires, and those who were not Saudi social media users were excluded. In total, 322 questionnaires were collected, and 241 were finally analyzed in this study ( 81 questionnaires were excluded). Thus, the response rate was $74.8 \%$ and the research model was tested statistically using this sample of 241 respondents who had accounts on social media.

\subsection{Data Collection Instrument}

The variables in this study were measured using a 5-point Likert scale, ranging from "strongly agree" (5) to "strongly disagree (1). Measurement items were adapted from existing scales found in relevant marketing literature. Perceived social media marketing was measured by using four items adapted from Kim and Ko (2012) and Ismail (2007). Value consciousness was measured by using four items adapted from Lichtenstein et al. (1993). Brand consciousness was measured by using four items adapted from Sproles and Kendall (1986). Brand loyalty was measured by using four items adapted from Ailawadi et al. (2001). eWOM was measured by using six items adapted from Bambauer-Sachse \& Mangold (2011), and two items adapted from Walsh et al. (2009). Purchase intention was measured by using four items adapted from Coyle and Thorson (2001), and two items adapted from McKnight and Chervany (2002).

The questionnaire was administered in the English and Arabic languages. Content Validity method is used to measure the questionnaire's validity. The original scales were in English language and to ensure that the original items were translated correctly, a back-translation process was used (Craig \& Douglas, 2000). Back translation was conducted by three professors of marketing and management to maintain the consistency of the original meaning, and to ensure that the constructs and items represent the original scales. 


\subsection{Data Analysis: Statistical Analysis Techniques}

The research model has been tested using the partial least squares (PLS) technique, a variance-based structural equation modeling (SEM) method and complemented using SPSS 22. This study uses SmartPLS 3.0 software for the PLS analysis, in a two-stage approach, measurement and structural model testing. The chi-square test and overall model fit indices GFI, NFI, CFI, TLI, RMR and RMSEA on AMOS 22 were used to further evaluate the model fit.

\section{Results}

The profile of the sample of 241 respondents has been obtained by the online survey. $47.3 \%$ were Saudi male and $52.7 \%$ were Saudi female. The respondents were in different age groups, from below 20 years old (19.1\%) to above 40 years old $(2.1 \%)$. A majority of the sample, $63.9 \%$, were in the age group of $21-30$ years old. The educational level of the sample was from high school, $12.4 \%$, to $\mathrm{PhD}$ level, $1.2 \%$. A majority of the sample, $73.4 \%$, had a bachelor's level of education. The usage of social media varied from everyday, to $4-5$ times a week, once or twice a week, or very rare, where $95.4 \%$ of the respondents used social media everyday, while $0.4 \%$ used it very rarely. Most of the respondents used social media everyday (95.4\%). The respondents had accounts on one or more of the social media sites including Twitter, Snapchat, Instagram, Google +, and Facebook. Most of the respondents used Twitter and Snapchat, $84.2 \%$ and $87.1 \%$ respectively, while the least popular social media site is Facebook, 19.5\%. 98.7\% of the sample, 238 respondents, used social media sites to purchase products from one or more of the categories of books/magazines and newspapers, computer hardware/software and electronics, hair and skin products, event tickets, travel/hotel arrangement and others. Only 3 of the respondents, $1.2 \%$ did not purchase through social media sites. A majority of the respondents, $64.7 \%$, used social media sites to purchase clothing and accessories. Table 1 presents the characteristics of the sample.

Table 1. Characteristics of the sample

\begin{tabular}{|c|c|c|}
\hline \multicolumn{3}{|l|}{ Gender } \\
\hline Male & 114 & $47.3 \%$ \\
\hline Female & 127 & $52.7 \%$ \\
\hline \multicolumn{3}{|l|}{ Age } \\
\hline 20 years old or under & 46 & $19.1 \%$ \\
\hline 21-30 years old & 154 & $63.9 \%$ \\
\hline $31-40$ years old & 36 & $14.9 \%$ \\
\hline 41 years old and above & 5 & $2.1 \%$ \\
\hline \multicolumn{3}{|l|}{ Education Level } \\
\hline High School & 30 & $12.4 \%$ \\
\hline Diploma & 6 & $2.5 \%$ \\
\hline Bachelor's & 177 & $73.4 \%$ \\
\hline Master's & 25 & $10.4 \%$ \\
\hline $\mathrm{PhD}$ & 3 & $1.2 \%$ \\
\hline \multicolumn{3}{|l|}{ Social Media Usage } \\
\hline Everyday & 230 & $95.4 \%$ \\
\hline 4-5 times a week & 5 & $2.1 \%$ \\
\hline Once or twice a week & 5 & $2.1 \%$ \\
\hline Very Rare & 1 & $0.4 \%$ \\
\hline \multicolumn{3}{|l|}{ Social Media Sites } \\
\hline Twitter & 203 & $84.2 \%$ \\
\hline Instagram & 188 & $78 \%$ \\
\hline Facebook & 47 & $19.5 \%$ \\
\hline Snapchat & 210 & $87.1 \%$ \\
\hline Google+ & 52 & $21.5 \%$ \\
\hline Others & 70 & $29 \%$ \\
\hline \multicolumn{3}{|l|}{ Products purchased on social media sites } \\
\hline Books, Magazines, newspapers & 47 & $19.5 \%$ \\
\hline Computer hardware/software, electronics & 92 & $38.2 \%$ \\
\hline Hair and skin products & 70 & $29 \%$ \\
\hline Event tickets & 68 & $28.2 \%$ \\
\hline Clothing and accessories & 156 & $64.7 \%$ \\
\hline Travel/Hotel arrangement & 121 & $50.2 \%$ \\
\hline Others & 56 & $23.2 \%$ \\
\hline None & 3 & $1.2 \%$ \\
\hline
\end{tabular}

Source: Own Elaboration. 
The measurement model is assessed by examining the reliability, convergent validity and discriminant validity. The construct reliability is assessed using Cronbach's $\alpha$ and composite reliability. The reliability of the measurement items was verified using Cronbach's $\alpha$ to assess the internal consistency of the constructs in the applied model. The level of internal consistency for each construct was acceptable, with the Cronbach's alpha ranging from 0.667 to 0.806 (Table 2). This exceeded the rule of using the reliability level of 0.5 (Hair et al., 2006). Thus, the analysis indicated that the measurement scales are highly reliable. The composite reliability (CR) values ranged from 0.76 to 0.86 (Table 2). This is greater than the value of 0.7 and indicates the valid reliability criteria. The convergent validity is assessed by calculating the loading factor for each item and the values of average variance extracted (AVE) to be greater than 0.5 (Hair et al., 2006). All item loadings are greater than 0.6 and the AVE values ranged from 0.51 to 0.62 (Table 2). Thus, the convergent validity of the constructs is confirmed. Items with loading factors less than 0.6 were removed. These include SMM3, BC4, VC4, eWOM1, eWOM2, eWOM5, eWOM6 and PI6 (Refer to Appendix A Measures).

Table 2. Results of construct assessment

\begin{tabular}{|c|c|c|c|c|c|c|c|}
\hline & & Mean & SD & $\begin{array}{l}\text { Factor } \\
\text { loading }\end{array}$ & CR & Cronbach's $\alpha$ & AVE \\
\hline \multicolumn{8}{|c|}{ Social Media Marketing } \\
\hline SMM1 & $\begin{array}{l}\text { I find interesting contents shown in social media } \\
\text { about the brand I am considering to buy. }\end{array}$ & 4.046 & 0.894 & 0.726 & 0.777 & 0.676 & 0.537 \\
\hline SMM2 & $\begin{array}{l}\text { It is easy to deliver my opinion about the brand I am } \\
\text { considering buying through social media. }\end{array}$ & 3.996 & 0.936 & 0.705 & & & \\
\hline SMM4 & $\begin{array}{l}\text { I would like to pass along information on brand, } \\
\text { product, or services from social media to my friends. }\end{array}$ & 3.934 & 0.922 & 0.767 & & & \\
\hline \multicolumn{8}{|c|}{ Brand Consciousness } \\
\hline BC1 & $\begin{array}{l}\text { I pay attention to the brand names of the products I } \\
\text { buy. }\end{array}$ & 4.01 & 1.07 & 0.708 & 0.764 & 0.667 & 0.523 \\
\hline BC2 & $\begin{array}{l}\text { Brand names tell me something about the quality of } \\
\text { the products. }\end{array}$ & 4.079 & 0.989 & 0.830 & & & \\
\hline BC3 & $\begin{array}{l}\text { Sometimes I am willing to pay more money for } \\
\text { products because of its brand name. }\end{array}$ & 3.917 & 1.153 & 0.716 & & & \\
\hline \multicolumn{8}{|c|}{ Value Consciousness } \\
\hline VC1 & $\begin{array}{l}\text { I am very concerned about low prices, but I am } \\
\text { equally concerned about product quality. }\end{array}$ & 3.876 & 1.127 & 0.768 & 0.835 & 0.704 & 0.628 \\
\hline $\mathrm{VC2}$ & $\begin{array}{l}\text { When shopping, I compare the prices of different } \\
\text { brands to be sure I get the best value for the money. }\end{array}$ & 3.88 & 1.085 & 0.842 & & & \\
\hline VC3 & $\begin{array}{l}\text { When purchasing a product, I always try to maximize } \\
\text { the quality I get for the money I spend. }\end{array}$ & 3.544 & 1.294 & 0.765 & & & \\
\hline \multicolumn{8}{|c|}{ Brand Loyalty } \\
\hline BL1 & $\begin{array}{l}\text { I would rather stick with a brand I usually buy than } \\
\text { try something I am not very sure of. }\end{array}$ & 3.61 & 1.017 & 0.709 & 0.855 & 0.773 & 0.596 \\
\hline BL2 & I have certain types of brands that I always buy. & 3.718 & 1.052 & 0.825 & & & \\
\hline BL3 & I consider myself to be loyal to one brand of product & 3.178 & 1.187 & 0.721 & & & \\
\hline BL4 & I feel confidence in a brand that I always buy. & 3.896 & 0.999 & 0.826 & & & \\
\hline \multicolumn{8}{|c|}{ e-Word of Mouth } \\
\hline eWOM3 & $\begin{array}{l}\text { I often consult other consumers' online product } \\
\text { reviews to help choose the right brand. }\end{array}$ & 3.68 & 1.128 & 0.718 & 0.807 & 0.685 & 0.511 \\
\hline eWOM4 & $\begin{array}{l}\text { I frequently gather information from online } \\
\text { consumers' product reviews before I buy a certain } \\
\text { brand. }\end{array}$ & 3.967 & 1.018 & 0.704 & & & \\
\hline eWOM7 & $\begin{array}{l}\text { If I were asked, I would recommend becoming a } \\
\text { customer of the brand. }\end{array}$ & 3.664 & 0.859 & 0.751 & & & \\
\hline eWOM8 & $\begin{array}{l}\text { I would recommend this brand to friends and } \\
\text { acquaintances. }\end{array}$ & 4.012 & 0.786 & 0.725 & & & \\
\hline
\end{tabular}




\begin{tabular}{|c|c|c|c|c|c|c|c|}
\hline \multicolumn{8}{|c|}{ Purchase Intention } \\
\hline PI1 & $\begin{array}{l}\text { It is very likely that I will buy the brands } \\
\text { recommended by my friends on social media sites. }\end{array}$ & 3.768 & 0.881 & 0.704 & 0.865 & 0.806 & 0.562 \\
\hline PI2 & $\begin{array}{l}\text { I will purchase the brands as marketed on social } \\
\text { media sites the next time I need a product. }\end{array}$ & 3.34 & 0.986 & 0.724 & & & \\
\hline PI3 & $\begin{array}{l}\text { I will definitely try the brand as marketed on social } \\
\text { media sites. }\end{array}$ & 3.108 & 1.103 & 0.788 & & & \\
\hline PI4 & $\begin{array}{l}\text { I will recommend the brand on social media sites to } \\
\text { my friends. }\end{array}$ & 3.432 & 1.053 & 0.811 & & & \\
\hline PI5 & $\begin{array}{l}\text { Using social networking sites of brands helps me } \\
\text { make decisions better before purchasing goods and } \\
\text { services. }\end{array}$ & 3.838 & 0.913 & 0.725 & & & \\
\hline
\end{tabular}

The discriminant validity among the constructs is calculated by the correlation matrix. The correlations for the constructs are shown in Table 3. These measurement results are satisfactory and suggest that it is appropriate to proceed with the evaluation of the structural model. Moreover, assessment of nomological validity is based on the correlation matrix (Hair et al., 2006). The results support that these constructs are positively related to one another and these relationships simply make sense.

Table 3. Correlation matrix

\begin{tabular}{|c|c|c|c|c|c|c|}
\hline & $\begin{array}{l}\text { Perceived Social Media } \\
\text { Marketing Activities }\end{array}$ & $\begin{array}{l}\text { Brand } \\
\text { Consciousness }\end{array}$ & $\begin{array}{l}\text { Value } \\
\text { Consciousness }\end{array}$ & $\begin{array}{l}\text { Brand } \\
\text { Loyalty }\end{array}$ & E-WOM & $\begin{array}{l}\text { Purchase } \\
\text { Intention }\end{array}$ \\
\hline Perceived Social Media & 0.733 & & & & & \\
\hline \multicolumn{7}{|l|}{ Marketing Activities } \\
\hline Brand Consciousness & 0.397 & 0.723 & & & & \\
\hline Value Consciousness & 0.468 & 0.240 & 0.792 & & & \\
\hline Brand Loyalty & 0.369 & 0.282 & 0.443 & 0.772 & & \\
\hline e-WOM & 0.340 & 0.234 & 0.304 & 0.357 & 0.715 & \\
\hline Purchase Intention & 0.325 & 0.154 & 0.294 & 0.318 & 0.598 & 0.750 \\
\hline
\end{tabular}

To assess the multicollinearity in the inner (structural) model, VIF (Variance Inflation Factor) criteria is applied. The structural VIF coefficients should not be higher than 4.0 (Hair et al., 2014). All VIF values for all research items are above the acceptable value. Table 4 shows the VIF results.

Table 4. VIF testing results

\begin{tabular}{ll}
\hline & VIF \\
\hline Perceived social media marketing activities & \\
SMM1 & 1.258 \\
SMM2 & 1.162 \\
SMM4 & 1.156 \\
Brand Consciousness & \\
BC1 & 1.078 \\
BC2 & 1.317 \\
BC3 & 1.280 \\
Value Consciousness & \\
VC1 & 1.328 \\
VC2 & 1.476 \\
VC3 & 1.358 \\
Brand Loyalty & \\
BL1 & 1.339 \\
BL2 & 1.726 \\
BL3 & 1.456 \\
BL4 & 1.685 \\
eWOM & \\
eWOM3 & 1.486 \\
\hline
\end{tabular}




\begin{tabular}{ll}
\hline eWOM4 & 1.524 \\
eWOM7 & 1.352 \\
eWOM8 & 1.328 \\
Purchase Intention & \\
PI1 & 1.337 \\
PI2 & 1.722 \\
PI3 & 1.910 \\
PI4 & 1.916 \\
PI5 & 1.378 \\
\hline
\end{tabular}

Furthermore, the model fit indices of the structural model is presented in the Table 5. The goodness-of fit statistics show that the structural model fit the data reasonably well. Chi -square for this model is 442.759 (d.f = $194, p=0.000$ ). The value of Chi-square divided by the degrees of freedom gives the re-estimated chi-square value of 2.282. This is within the appropriate range from 1-5. RMSEA fit index is 0.073 , which is smaller than 0.1 . These indicate the model has a good fit. Other goodness of fit indices $(\mathrm{GFI}=.859, \mathrm{CFI}=.859, \mathrm{NFI}=.750$, $\mathrm{TLI}=.808$ ) indicate the structural model was a reasonable fit.

Table 5. Model fit statistics

\begin{tabular}{llllllll}
\hline & Chi-square/df & RMSEA & RMR & NFI & CFI & TLI & GFI \\
\hline Accepted values & $<5$ & $<0.1$ & $<0.5$ & $>0.9$ & $>0.9$ & $>0.9$ & $>0.9$ \\
Calculated values & 2.282 & 0.073 & 0.074 & 0.750 & 0.839 & 0.808 & 0.859 \\
\hline
\end{tabular}

The bootstrapping method in SmartPLS software was used to test the statistical significance of the path coefficients. Figure 2 shows the P value for all research variables and the PLS Model of the study.

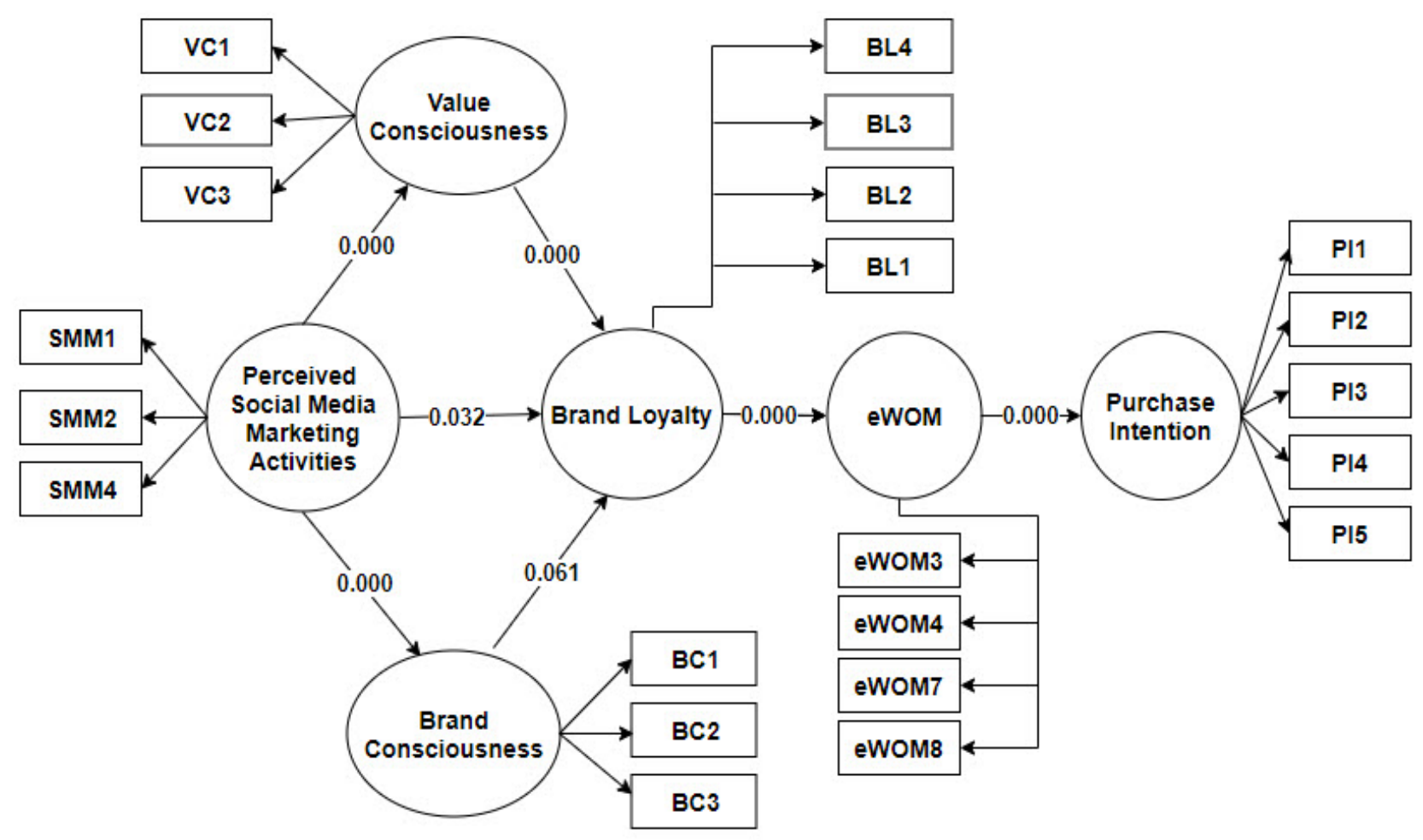

Figure 2. Result of PLS-SEM

Hypothesis paths testing is conducted and hypotheses are accepted for $p \leq 0.05$ and rejected for $p \geq 0.05$. Results demonstrate that perceived social media marketing activities have a direct significant statistical impact on brand 
loyalty (H1). Perceived social media marketing activities have a direct significant statistical impact on value consciousness (H2) and it explains around $22 \%$ of value consciousness variance. Value consciousness has a direct significant statistical impact on brand loyalty (H3). Perceived social media marketing activities have a significant statistical impact on brand consciousness (H4) and it explains around $15 \%$ of brand consciousness variance.

Interestingly, there is no direct significant statistical impact of brand consciousness on brand loyalty ( $\mathrm{p} \leq 0.05)$. Therefore, the results do not support H5. Moreover, perceived social media marketing activities, value consciousness and brand consciousness explain together around $24 \%$ of brand loyalty variance.

Results also prove that perceived social media marketing activities have a direct significant statistical impact on brand loyalty as mediated by value consciousness $(\mathrm{H} 7)$, while they reject the claim that perceived social media marketing activities have a direct significant statistical impact on brand loyalty as mediated by brand consciousness (H6). Thus, H6 is not supported.

Results support the hypothesis that brand loyalty has a significant statistical impact on eWOM (H8). Brand loyalty explains $12 \%$ of eWOM variance. Results also demonstrate that eWOM has a significant statistical impact on purchase intention (H9) and eWOM explains around 35\% of purchase intention variance. Moreover, perceived social media marketing activities have a direct significant statistical impact on purchase intention (H10). Table 6 presents a summary of the results of hypotheses testing.

Table 6. Summary of hypothesis testing results

\begin{tabular}{|c|c|c|c|c|c|}
\hline & Path & $\begin{array}{l}\text { Standard } \\
\text { Deviation }\end{array}$ & $t$-statistics & $\begin{array}{l}p \\
\text { Values }\end{array}$ & Result \\
\hline H1 & Perceived social media marketing $\rightarrow$ Brand Loyalty & 0.063 & 6.327 & 0.000 & Supported \\
\hline $\mathbf{H} 2$ & Perceived social media marketing activities $\rightarrow$ Value consciousness & 0.073 & 2.146 & 0.032 & Supported \\
\hline H3 & Value Consciousness $\rightarrow$ Brand Loyalty & 0.066 & 7.140 & 0.000 & Supported \\
\hline H4 & $\begin{array}{l}\text { Perceived Social Media Marketing activities } \rightarrow \text { Brand } \\
\text { Consciousness }\end{array}$ & 0.063 & 6.327 & 0.000 & Supported \\
\hline H5 & Brand Consciousness $\rightarrow$ Brand Loyalty & 0.074 & 1.879 & 0.061 & Not \\
\hline H6 & $\begin{array}{l}\text { Perceived Social Media Marketing activities } \rightarrow \text { Brand } \\
\text { Consciousness } \rightarrow \text { Brand Loyalty }\end{array}$ & 0.031 & 1.764 & 0.078 & Not \\
\hline H7 & $\begin{array}{l}\text { Perceived Social Media Marketing activities } \rightarrow \text { Value } \\
\text { consciousness } \rightarrow \text { Brand Loyalty }\end{array}$ & 0.039 & 4.079 & 0.000 & Supported \\
\hline H8 & Brand Loyalty $\rightarrow$ eWOM & 0.064 & 5.586 & 0.000 & Supported \\
\hline H9 & eWOM $\rightarrow$ Purchase Intention & 0.046 & 13.092 & 0.000 & Supported \\
\hline H10 & Perceived Social Media Marketing activities $\rightarrow$ Purchase Intention & 0.055 & 2.565 & 0.011 & Supported \\
\hline
\end{tabular}

\section{Discussion, Conclusion and Recommendations}

The major contribution of this study is to develop an understanding of the impact of social media marketing in the context of Saudi users of social media. The research investigated the impact of social media marketing on brand loyalty, brand consciousness, value consciousness, and purchase intention; the mediating effects of brand consciousness and value consciousness on the relationship between perceived social media marketing activities and brand loyalty; the impact of brand loyalty on eWOM; and the impact of eWOM on purchase intention. The overall analysis provides a strong relation of perceived social media marketing activities on brand loyalty, brand consciousness, value consciousness and purchase intentions. It gives a clearer picture regarding the influence of social media marketing activities of brands on customers who value brand names, and on customers who seek value for money. It is found that this marketing channel impacts both these brand conscious and value conscious consumers. According to the findings presented in this study, it is evident that social media marketing activities increase the trust of the customer in the brand, and their willingness to purchase the brands, thereby, influencing brand loyalty and purchase intentions. This study confirms the effect of social media marketing on brand loyalty, brand consciousness and value consciousness. It also confirms the mediation effect of value consciousness on the relationship between social media marketing activities and brand loyalty. However, our results found that brand consciousness does not have a direct significant statistical impact on brand loyalty, and also rejects the claim that perceived social media marketing has an indirect significant statistical impact on brand loyalty as mediated by brand consciousness. Moreover, the research findings agree with Tiago and Verissimo (2014) who suggest that brand loyalty is associated with diffusing positive eWOM. This study confirms the significant impact of brand loyalty on eWOM. It shows that eWOM has an impact on purchase intentions, which gives the 
reason why when consumers who are brand loyal diffuse eWOM messages and this influences the other consumers who receive this information and motivates them to buy or not to buy. Finally, our assumption that social media marketing activities have a direct effect on purchase intentions is believed to be valid. When consumers receive commercial messages, interact with and are informed about brands, it influences their purchase intentions significantly.

The study is useful for scholars and practitioners to understand the impact of social media marketing activities. Based on these findings, it can be concluded that Saudi consumers these days are heavy users of social media and are highly influenced by social media messages in their purchase process. Marketers of the products they purchase mostly through social media can utilize the channel more effectively. Marketers and practitioners must understand the importance of this channel in Saudi society, and elsewhere, as an effective tool for marketing and incorporate this medium in their marketing communication mix. Social media marketing channel will be an effective tool in Saudi Arabia for marketing products that Saudi consumers mostly purchase through this channel. According to the research findings, marketers of clothing and accessories, computer hardware/software and electronics, and travel arrangements should use the medium to communicate with Saudi consumers on their most used platforms which are Twitter, Instagram and Snapchat. Focusing on promoting the brand through this media channel will boost awareness, build customer's brand loyalty and differentiate the brand in the minds of consumers. The organization's marketing plans must be accompanied by strategies on social media platforms to increase networking, community building and conversation between the brands and consumers. Typically consumers who are social media users rely on commercial messages through pictures, product reviews, ratings, and comments on social media sites. So in order to increase profits in the long run and strengthen brand loyalty, it is suggested to inform and update the consumers about the products on networking sites, blogs, new sites and forums, and to build relationships with customers through online communities. Since consumers are either brand conscious or value conscious, social media marketing efforts should be different for the two. Offers for 'low prices and quality products' on social media sites would be effective for value conscious consumers and increase their interest in buying. The findings suggest that value conscious consumers are brand loyal and social media marketing activities for them will help build brand loyalty. For brand conscious consumers, marketers can promote the expensive, high quality brands with keeping their value for prestige in mind while designing the strategies for social media marketing. To increase diffusion of eWOM messages, marketers must form blogs, virtual communities, newsgroups, product review websites, or fan clubs that will eventually affect their purchase intentions.

\subsection{Limitations and Further Research}

This research has certain limitations. The sample in this study is the Saudi social media users, and not other countries. Therefore generalizations for the entire population of social media users or for other countries are inappropriate. It would be interesting to analyze whether the effects are the same when conducting the study in other countries or regions. Second, the respondents were of various age groups and education levels. Future studies can investigate the model with a sample based on specific education level, or age. Other factors that are influenced by social media marketing activities can be included to refine the model. The model can further be investigated with moderating variables such as gender, age and social media usage time. The study can be applied to specific industries, and the model for individual brands. Moreover, limited research has been conducted in previous studies with these variables. Further research is suggested to study the relationship among these variables.

\section{Acknowledgement}

The research is supervised by Dr. Soad Al Meshal, Assistant Professor of Marketing at King Saud University in the Kingdom of Saudi Arabia. The professor can be contacted at salmeshal@ksu.edu.sa.

The authors extend appreciation to the Deanship of Scientific Research at King Saud University for supporting this research through the Research Center of the College of Business Administration.

\section{References}

Aaker, D. A. (1991). Managing Brand Equity: Capitalizing on the Value of a Brand Name. New York: The Free Press.

Aburdene, P. (2005). Megatrends 2010: The rise of conscious capitalism. Charlottesville, VA: Hampton Roads Publishing Company.

Ailawadi, K. L., Neslin, S. A., \& Gedenk, K. (2001). Pursuing the value-conscious consumer: store brands versus national brand promotions. Journal of Marketing, 65(1), 71-89. 
https://doi.org/10.1509/jmkg.65.1.71.18132

Alves, H., Fernandes, C., \& Raposo, M. (2016). Social Media Marketing; A Literature Review and Implications. Psychology and Marketing, 33(12), 1029-1038. https://doi.org/10.1002/mar.20936

Bambauer-Sachse, S., \& Mangold, S. (2011). Brand equity dilution through negative online word-of-mouth communication. Journal of Retailing and Consumer Services, 18(1), 38-45. https://doi.org/10.1016/j.jretconser.2010.09.003

Bao, Y., \& Mandrik, C. A. (2004). Discerning store brand users from value consciousness consumers: the role of prestige sensitivity and need for cognition. ACR North American Advances.

Bong, W. Z. (2017). Influence of Social Media Marketing, Brand Loyalty and eWOM Towards Consumers' Purchase Intention (Doctoral dissertation, UTAR).

Burmann, C. (2010). A call for "user-generated branding." Journal of Brand Management, 18(1), 1-4. https://doi.org/10.1057/bm.2010.30

Cambria, E., Grassi, M., Hussain, A., \& Havasi, C. (2012). Sentic computing for social media marketing. Multimedia tools and applications, 59(2), 557-577. https://doi.org/10.1007/s11042-011-0815-0

Chan, N. L., \& Guillet, B. D. (2011). Investigation of social media marketing: how does the hotel industry in Hong Kong perform in marketing on social media websites? Journal of Travel \& Tourism Marketing, 28(4), 345-368. https://doi.org/10.1080/10548408.2011.571571

Choi, Y., Thoeni, A., \& Kroff, M. W. (2018). Brand Actions on Social Media: Direct Effects on Electronic Word of Mouth (eWOM) and Moderating Effects of Brand Loyalty and Social Media Usage Intensity. Journal of Relationship Marketing, 17(1), 52-70. https://doi.org/10.1080/15332667.2018.1440140

Coyle, J. R., \& Thorson, E. (2001). The effects of progressive levels of interactivity and vividness in web marketing sites. Journal of advertising, 30(3), 65-77. https://doi.org/10.1080/00913367.2001.10673646

Craig, C. S., \& Douglas, S. P. (2000). Configural advantage in global markets. Journal of International Marketing, 8(1), 6-26. https://doi.org/10.1509/jimk.8.1.6.19564

Doh, S. J., \& Hwang, J. S. (2009). How consumers evaluate eWOM (electronic word-of-mouth) messages. CyberPsychology \& Behavior, 12(2), 193-197. https://doi.org/10.1089/cpb.2008.0109

Erdoğmuş, İ. E., \& Cicek, M. (2012). The impact of social media marketing on brand loyalty. Procedia-Social and Behavioral Sciences, 58, 1353-1360. https://doi.org/10.1016/j.sbspro.2012.09.1119

Fishbein, M., \& Ajzen, I. (1975). Belief, attitude, intention and behavior: An introduction to theory and research. Reading, MA: Addison-Wesley.

Fournier, S. (1998). Consumers and their brands: Developing relationship theory in consumer research. Journal of consumer research, 24(4), 343-373. https://doi.org/10.1086/209515

Global Media Insight. (2018). Saudi Arabia Social Media Statistics 2018. Retrieved from https://www.globalmediainsight.com/blog/saudi-arabia-social-media-statistics/

Gunelius, S. (2011). 30-minute social media marketing. McGraw-Hill: USA.

Hair Jr, J. F., Sarstedt, M., Hopkins, L., \& Kuppelwieser, V. G. (2014). Partial least squares structural equation modeling (PLS-SEM) An emerging tool in business research. European Business Review, 26(2), 106-121. https://doi.org/10.1108/EBR-10-2013-0128

Hair, J. F., Black, W. C., Babin, B. J., Anderson, R. E., \& Tatham, R. L. (2006). Multivariate data analysis (Vol. $6)$.

Hajli, N. M. (2014). A study of the impact of social media on consumers. International Journal of Market Research, 56(3), 387-404. https://doi.org/10.2501/IJMR-2014-025

Hennig-Thurau, T., Gwinner, K. P., Walsh, G., \& Gremler, D. D. (2004). Electronic word-of-mouth via consumer-opinion platforms: What motivates consumers to articulate themselves on the Internet? Journal of Interactive Marketing, 18(1), 38-52. https://doi.org/10.1002/dir.10073

Ismail, A. R. (2017). The influence of perceived social media marketing activities on brand loyalty: The mediation effect of brand and value consciousness. Asia Pacific Journal of Marketing and Logistics, 29(1), 129-144. https://doi.org/10.1108/APJML-10-2015-0154

Jalilvand, M. R., \& Samiei, N. (2012). The Effect of Electronic Word of Mouth on Brand Image and Purchase 
Intention. Marketing Intelligence and Planning, 30(4). https://doi.org/10.1108/02634501211231946

Kaplan, A. M., \& Haenlein, M. (2010). Users of the world, unite! The challenges and opportunities of Social Media. Business horizons, 53(1), 59-68. https://doi.org/10.1016/j.bushor.2009.09.003

Kim, A. J. Y., \& Ko, E. J. (2010). The impact of design characteristics on brand attitude and purchase intention-focus on luxury fashion brands. Journal of the Korean Society of Clothing and Textiles, 34(2), 252-265. https://doi.org/10.5850/JKSCT.2010.34.2.252

Kim, A. J., \& Ko, E. (2012). Do social media marketing activities enhance customer equity? An empirical study of luxury fashion brand. Journal of Business Research, 65(10), 1480-1486. https://doi.org/10.1016/j.jbusres.2011.10.014

Kim, H. J., \& Lee, H. Z. (2009). The effect of the well-being consumer value orientations, the perceived value and brand preference on purchase intention of the environment-friendly cosmetic. $J$ Korean Soc Clothing Ind, 15(1), 327-348.

Kim, J., Kim, J. E., \& Johnson, K. K. (2010). The customer-salesperson relationship and sales effectiveness in luxury fashion stores: the role of self monitoring. Journal of Global Fashion Marketing, 1(4), 230-239. https://doi.org/10.1080/20932685.2010.10593074

Kotler, P., Bowen, J. T., \& Makens, J. C. (2006). Marketing for hospitality and tourism. Upper Saddle River, NJ: Pearson Prentice Hall.

Kozinets, R. V., De Valck, K., Wojnicki, A. C., \& Wilner, S. J. (2010). Networked narratives: Understanding word-of-mouth marketing in online communities. Journal of marketing, 74(2), 71-89. https://doi.org/10.1509/jm.74.2.71

Lachance, M. J., Beaudoin, P., \& Robitaille, J. (2003). Adolescents' brand sensitivity in apparel: influence of three socialization agents. International Journal of Consumer Studies, 27(1), 47-57. https://doi.org/10.1046/j.1470-6431.2003.00261.x

Leung, X. Y., Bai, B., \& Stahura, K. A. (2015). The marketing effectiveness of social media in the hotel industry: A comparison of Facebook and Twitter. Journal of Hospitality \& Tourism Research, 39(2), 147-169. https://doi.org/10.1177/1096348012471381

Liao, J., \& Wang, L. (2009). Face as a mediator of the relationship between material value and brand consciousness. Psychology and Marketing, 26(11), 987-1991. https://doi.org/10.1002/mar.20309

Lichtenstein, D. R., Netemeyer, R. G., \& Burton, S. (1990). Distinguishing coupon proneness from value consciousness: an acquisition-transaction utility theory perspective. Journal of Marketing, 54(3), 54-67. https://doi.org/10.1177/002224299005400305

Lloyd, A. E., \& Luk, S. T. K. (2010). The devil wears Prada or Zara: a revelation into customer perceived value of luxury and mass fashion brands. $J$ Glob Fashion Mark, 1(3), 129-141. https://doi.org/10.1080/20932685.2010.10593065

Lobschat, L., Zinnbauer, M. A., Pallas, F., \& Joachimsthaler, E. (2013). Why social currency becomes a key driver of a firm's brand equity-Insights from the automotive industry. Long Range Planning, 46(1-2), 125-148. https://doi.org/10.1016/j.lrp.2012.11.004

Mangold, W. G., \& Faulds, D. J. (2009). Social media: The new hybrid element of the promotion mix. Business horizons, 52(4), 357-365. https://doi.org/10.1016/j.bushor.2009.03.002

McKee, S. (2010). Creative B2b Branding (No, Really): Building a Creative Brand in a Business World, Goodfellow Publishers Limited; USA.

McKnight, D. H., \& Chervany, N. L. (2002). What trust means in e-commerce customer relationships: An interdisciplinary conceptual typology. International Journal of Electronic Commerce, 6(2), 35-59. https://doi.org/10.4172/2168-9601.1000190

McKnight, D. H., Choudhury, V., \& Kacmar, C. (2002). Developing and validating trust measures for e-commerce: An integrative typology. Information Systems Research, 13(3), 334-359. https://doi.org/10.1287/isre.13.3.334.81

Nelson, M. R., \& McLeod, L. E. (2005). Adolescent brand consciousness and product placements: awareness, liking and perceived effects on self and others. International Journal of Consumer Studies, 29(6), 515-528. https://doi.org/10.1111/j.1470-6431.2005.00429.x 
Reichheld, F. F., Teal, T., \& Smith, D. K. (1996). The loyalty effect. Boston, MA: Harvard Business School Press.

Rezvani, S., Dehkordi, G. J., Rahman, M. S., Fouladivanda, F., Habibi, M., \& Eghtebasi, S. (2012). A conceptual study on the country of origin effect on consumer purchase intention. Asian Social Science, 8(12), 205. https://doi.org/10.5539/ass.v8n12p205

Rialti, R., Zollo, L., Pellegrini, M. M., and Ciappei, C. (2017). Exploring the antecedents of brand loyalty and electronic word of mouth in social-media-based brand communities: do gender differences matter? Journal of Global Marketing, 30(3), 147-160. https://doi.org/10.1080/08911762.2017.1306899

Smith, A. N., Fischer, E., \& Yongjian, C. (2012). How does brand-related user-generated content differ across YouTube, Facebook, and Twitter? Journal of interactive marketing, 26(2), 102-113. https://doi.org/10.1016/j.intmar.2012.01.002

Sproles, G., \& Kendall, E. (1986). A methodology for profiling consumers' decision making styles. Journal of Consumer Affairs, 20(2), 267-279. https://doi.org/10.1111/j.1745-6606.1986.tb00382.x

Statista. (2017). Penetration of leading social networks in Saudi Arabia as of 3rd quarter 2017. Retrieved from https://www.statista.com/statistics/284451/saudi-arabia-social-network-penetration/

Stileman, P. (2009). To what extent has social media changed the relationship between brand and consumer. Bucks New University: MA Advertising.

Tiago, M. T. P. M. B., \& Veríssimo, J. M. C. (2014). Digital marketing and social media: Why bother? Business Horizons, 57(6), 703-708. https://doi.org/10.1016/j.bushor.2014.07.002

Torlak, O., Ozkara, B. Y., Tiltey, M. A., Cengiz, H., \& Dulger, M. F. (2014).The Effect of Electronic Word of Mouth on Brand Image and Purchase Intention; An Application Concerning Cell Phone Brands for Youth Consumers in Turkey. Journal of Marketing Development and Competitiveness, 8(2), 61-68.

Tuten, T. L. (2008). Advertising 2.0: Social Media Marketing in a Web 2.0 World, Greenwood Publishing Group, London.

Walsh, G., Mitchell, V. W., Jackson, P. R., \& Beatty, S. E. (2009). Examining the antecedents and consequences of corporate reputation: A customer perspective. British Journal of Management, 20(2), 187-203. https://doi.org/10.1111/j.1467-8551.2007.00557.x

Weinberg, T. (2009). The new community rules: Marketing on the social web. O'Reilly Media, Inc.

Westbrook, R. A. (1987). Product/consumption-based affective responses and postpurchase processes. Journal of Marketing Research, 258-270. https://doi.org/10.2307/3151636

Yeh, Y. H., \& Choi, S. M. (2011). MINI-lovers, maxi-mouths: An investigation of antecedents to eWOM intention among brand community members. Journal of Marketing Communications, 17(3), 145-162. https://doi.org/10.1080/13527260903351119

Yoo, B., \& Donthu, N. (2001). Developing and validating a multidimensional consumer-based brand equity scale. Journal of business research, 52(1), 1-14. https://doi.org/10.1016/S0148-2963(99)00098-3

Yu, Y., Duan, W., \& Cao, Q. (2013). The impact of social and conventional media on firm equity value: A sentiment analysis approach. Decision Support Systems, 55(4), 919-926. https://doi.org/10.1016/j.dss.2012.12.028

Zaglia, M. E. (2013). Brand communities embedded in social networks. Journal of Business Research, 66(2), 216-223. https://doi.org/10.1016/j.jbusres.2012.07.015

Zarella, D. (2010). The Social media Marketing Book. OReilly Media. Inc. Sebastapol, CA.

Zeithaml, V. A. (1988). Consumer perceptions of price, quality, and value - a means-end model and synthesis of evidence. Journal of Marketing, 52(3), 2-22. https://doi.org/10.1177/002224298805200302

Zhu, F., \& Zhang, X. (2010). Impact of online consumer reviews on sales: The moderating role of product and consumer characteristics. Journal of marketing, 74(2), 133-148. https://doi.org/10.1509/jm.74.2.133 


\section{Appendix A}

\section{Measures}

\begin{tabular}{|c|c|c|}
\hline Variable and Scales & & Items \\
\hline \multirow{3}{*}{$\begin{array}{l}\text { Social Media Marketing } \\
(\text { SMM) } \\
\text { Kim \& Ko (2012), Ismail } \\
(2017)\end{array}$} & $\begin{array}{l}\text { SMM1 } \\
\text { SMM2 }\end{array}$ & $\begin{array}{l}\text { I find interesting contents shown in social media about the brand I am considering to buy. } \\
\text { It is easy to deliver my opinion about the brand I am considering buying through social media. }\end{array}$ \\
\hline & SMM3 & $\begin{array}{l}\text { Using social media to search for information about the brand I am considering buying is very } \\
\text { trendy. }\end{array}$ \\
\hline & SMM4 & $\begin{array}{l}\text { I would like to pass along information on brand, product, or services from social media to my } \\
\text { friends. }\end{array}$ \\
\hline \multirow{4}{*}{$\begin{array}{l}\text { Brand Consciousness (BC) } \\
\text { Sproles and Kendall (1986) }\end{array}$} & $\mathrm{BC} 1$ & I pay attention to the brand names of the products I buy. \\
\hline & $\mathrm{BC} 2$ & Brand names tell me something about the quality of the products. \\
\hline & $\mathrm{BC} 3$ & Sometimes I am willing to pay more money for products because of its brand name. \\
\hline & $\mathrm{BC} 4$ & Branded products that cost a lot of money are good quality. \\
\hline \multirow{4}{*}{$\begin{array}{l}\text { Value Consciousness (VC) } \\
\text { Lichtenstein et al. (1993) }\end{array}$} & VC1 & I am very concerned about low prices, but I am equally concerned about product quality. \\
\hline & $\mathrm{VC} 2$ & $\begin{array}{l}\text { When shopping, I compare the prices of different brands to be sure I get the best value for the } \\
\text { money. }\end{array}$ \\
\hline & $\mathrm{VC} 3$ & When purchasing a product, I always try to maximize the quality I get for the money I spend. \\
\hline & VC4 & When I buy products, I like to be sure that I am getting my money’s worth. \\
\hline \multirow{4}{*}{$\begin{array}{l}\text { Brand Loyalty }(B L) \\
\text { Ailawadi et al. (2001) }\end{array}$} & BL1 & I would rather stick with a brand I usually buy than try something I am not very sure of. \\
\hline & BL2 & I have certain types of brands that I always buy. \\
\hline & BL3 & I consider myself to be loyal to one brand of product. \\
\hline & BL4 & I feel confidence in a brand that I always buy. \\
\hline \multirow{8}{*}{$\begin{array}{l}\text { eWOM } \\
\text { Bambauer-Sachse \& Mangold } \\
(2011) \\
\text { Walsh et al. (2009) }\end{array}$} & eWOM1 & $\begin{array}{l}\text { I often read other consumers' online product reviews to know what brands make good } \\
\text { impressions on others. }\end{array}$ \\
\hline & eWOM2 & To make sure I buy the right brand, I often read other consumers' online product reviews. \\
\hline & eWOM3 & I often consult other consumers' online product reviews to help choose the right brand. \\
\hline & eWOM4 & $\begin{array}{l}\text { I frequently gather information from online consumers' product reviews before I buy a certain } \\
\text { brand. }\end{array}$ \\
\hline & eWOM5 & $\begin{array}{l}\text { If I don't read consumers' online product reviews when I buy a brand, I worry about my } \\
\text { decision. }\end{array}$ \\
\hline & eWOM6 & $\begin{array}{l}\text { When I buy a brand, consumers' online product reviews make me confident in purchasing the } \\
\text { product/brand. }\end{array}$ \\
\hline & eWOM7 & If I were asked, I would recommend becoming a customer of the brand. \\
\hline & eWOM8 & I would recommend this brand to friends and acquaintances. \\
\hline \multirow{6}{*}{$\begin{array}{l}\text { Purchase Intention (PI) } \\
\text { Coyle \& Thorson, (2001), } \\
\text { McKnight and Chervany } \\
(2002)\end{array}$} & PI1 & It is very likely that I will buy the brands recommended by my friends on social media sites. \\
\hline & PI2 & I will purchase the brands as marketed on social media sites the next time I need a product. \\
\hline & PI3 & I will definitely try the brand as marketed on social media sites. \\
\hline & PI4 & I will recommend the brand on social media sites to my friends. \\
\hline & PI5 & $\begin{array}{l}\text { Using social networking sites of brands helps me make decisions better before purchasing } \\
\text { goods and services. }\end{array}$ \\
\hline & PI6 & Using social networking sites of brands increases my interest in buying products and services. \\
\hline
\end{tabular}

\section{Copyrights}

Copyright for this article is retained by the author, with first publication rights granted to the journal.

This is an open-access article distributed under the terms and conditions of the Creative Commons Attribution

license (http://creativecommons.org/licenses/by/4.0/). 